\title{
Enforcing Federal Supremacy: Relief Against Federal-State Regulatory Conflicts
}

\author{
William W. Schwarzer*
}

Off the coast of southern California lies Catalina Island which California claims as its own notwithstanding some thirty miles of Pacific Ocean separating the two. One may reach Catalina by boat or by plane, the latter operated by United Air Lines, an air carrier in interstate and intrastate commerce. This Catalina air service had been under the unchallenged jurisdiction of the Civil Aeronautics Board for twelve years when, in September, 1951, United received a letter from the California Public Utilities Commission "instructing" it to file its Catalina tariffs with the Commission. Then followed a series of conferences between United and the Commission in which United clained, and the Commission denied, that the $\mathrm{CAB}$ had exclusive jurisdiction over the Catalina operation. These conferences proved inconclusive and in June, 1952, United brought suit in the federal district court for declaratory relief against the Commission's attempt to interfere with the CAB's jurisdiction, United Air Lines, Inc., et al. v. Public Utilities Commission of California. ${ }^{1}$

United's problem was one that has become increasingly common with the steady expansion of administrative regulation by the states. Federal regulation having been extended to its constitutional limits in many fields, the system of federalism is now being put to the test with unprecedented frequency as state regulatory power is being pushed to its constitutional limits. ${ }^{2}$ The problems of federalism in action in such fields as labor relations, taxation and public utilities are before the public eye constantly. ${ }^{3}$ The United case sheds no light on the distribution of regulatory powers between state and federal governments. It is no less of interest, however, because it focuses on the practical problem of the litigant who is the object of regulation and is cauglit between the massive powers of governments in

* Member, California Bar.

The facts appear in the district court opinion. United Air Lines, Inc., et al. v. Public Utilities Commission of California, 109 F. Supp. 13 (N.D. Cal. 1952), rev'd, 346 U.S. 402 (1953).

2 Exainples of discussions of the substantive aspects of federal-state regulatory conflictswhich are beyond the scope of this paper-are Symposium: American Federalism: The General Perspective, 54 CoL. L. Rev. 489 et seq. (1954); Cox, Federalism in the Law of Labor Relations, 67 Harv. L. REv. 1297 (1954); Notes, 66 HARv. L. REv. 327 (1952), 60 Harv. L. REv. 262 (1946).

3 Note the President's appointment on July 10, 1953 of the Commission on Intergovernmental Relations. U.S. Governament Organzzation Mandal 45 (1954). Beset with its own problems of intra-commission relations, it has not yet issued a report. 
conflict. Such conflict may exist in various degrees of intensity-it can range anywhere between an outright federal prohibition of state regulation and effective operation of a federal regulatory scheme to Congressional silence from which a prohibition of state action is inferred. The issue to be examined in this article, however, is not whether a conflict exists but, assuming such a conflict, what and when relief is available in the federal courts against state administrative action on the ground of federal supremacy.4

The three-judge district court hearing the United case had no difficulty in finding that its jurisdiction had been properly invoked, ${ }^{5}$ that United's flight to Catalina was over the high seas and hence subject to the jurisdiction of the $\mathrm{CAB},{ }^{6}$ and that it should not await the decision of a state court on the question of the reach of a federal statute. It rendered judgment declaring the $\mathrm{CAB}$ to have exclusive jurisdiction over United's Catalina operation and enjoining the State Commission from invading this jurisdiction. The Supreme Court, on direct appeal, reversed per curiam, ${ }^{7}$ citing only Public Service Commission of Utah v. Wycoff Co., Inc. Justices Douglas and Reed dissented.

In the Wycoff case, the Utah Commission had filed a petition in the

4 "The Constitution, and the Laws of the United States which shall be made in Pursuance thereof; and all Treaties inade, or which shall be made, under the Authority of the United States, shall be the supreme Law of the Land: . . U. U.S. Const. ART. VI. The Supremacy Clause is a shield rather than a sword, however, and a suit for relief against state action based on it is not considered an attack on the constitutional validity of the state enactment. See note 51 infra.

5 Federal district courts have original jurisdiction over actions "arising under the Constitution, laws or treaties of the United States" where the amount in controversy exceeds $\$ 3000$ under 28 U.S.C. $\$ 1331$ (1952), and over actions "arising under any Act of Congress regulatnig commerce or protecting trade and commerce against restraints and monopolies." 28 U.S.C. $\S 1337$ (1952). The latter section requires no jurisdictional amount. See Food, Tobacco \& Agricultural Workers v. Smiley, 74 F. Supp. 823, 826 (E.D.Pa. 1946). In the United case jurisdiction was grounded on both sections. See also All American Airways v. Cedarhurst, 201 F.2d 273 (2d Cir. 1953). But this practice is vulnerable to a motion to strike the reference to one section or the other. American Amusement Co. v. Ludwig, 82 F. Supp. 265 (D. Minn. 1949). Most cases attacking state administrative action on the ground of conflict with federal law or regulation have rested on Section 1337 but there are exceptions. See Rice v. Santa Fe Elevator Corp., 331 U.S. 218 (1947) ; Cloverleaf Butter Co. v. Patterson, 315 U.S. 148 (1942). When, as in the latter two cases, Section 1331 is invoked, the jurisdictional amount may be established by a showing that the probable cost of a full hearing will exceed $\$ 3000$. Petroleum Exploration, Inc. v. Public Service Commission, 304 U.S. 209 (1938); see Note, 30 A.L.R.2d 602 (1953).

( The pertinent provision appears in 52 StaT. 973, 979 (1938), 49 U.S.C. $\$ 401$ (21) (\$) (1952).

7 Public Utilities Commission v. United Air Lines, Inc., 346 U.S. 402 (1953), reversing, 109 F. Supp. 13 (N.D. Cal. 1952). The case had been heard by a three-judge district court and appealed directly to the Supreme Court because United originally challenged also the constitutionality of the state law-but this point was abandoned. $I d$. at 15 . See note 51 infra.

8344 U.S. 237 (1952) (Reed. J., concurring; Douglas, J., dissenting). 
Utah court to enjoin Wycoff from operating between points within the state as a carrier of motion picture advertising and supplies because it lacked a state certificate. ${ }^{9}$ Process in that suit was never served, but Wycoff sued for injunctive and declaratory relief in the federal court, alleging that its operations were authorized by a certificate from the Interstate Commerce Commission. It asked for a declaration that its activities constituted interstate commerce but abandoned the prayer for injunctive relief. The district court sustained the Commission's contention that the activities were in intrastate commerce and hence not covered by the ICC certificate and dismissed the case. The court of appeals concluded that Wycoff's activities were an integral part of interstate commerce and reversed and remanded. ${ }^{10}$ On certiorari the Supreme Court found that Wycoff was not entitled to declaratory relief on the facts and ordered the case dismissed. Mr. Justice Jackson's opinion for the majority, which is incorporated as the majority opimion in the United case as well, made three points:

1. Plaintiff did not show that there was "any risk of suffering penalty, liability or prosecution"; the declaration requested was therefore abstract and anticipatory. ${ }^{11}$

2. "[T] he declaratory judgment procedure will not be used to preempt and prejudge issues that are committed for initial decision to an administrative body...."12

3. Declaratory relief would interfere with the right of state administrative bodies to reduce general state policy into concrete orders and would be incompatible with a proper federal-state relationship. ${ }^{13}$

In broadest outline, these are the procedural problems involved in the determination whether a federal court slould assume jurisdiction when relief is sought against threatened state administrative action alleged to conflict with federal law or regulation.

A

The inquiry whether the party asking rehef has proved "any risk of suffering penalty, liability or prosecution" that would justify relief is both conceptualistic and practical. It involves the fitting of the case into the traditional pigeonholes of "irreparable harm" or "justiciable controversy."

9 Prior to the filing of this petition, Wycoff had applied to the Utah commission for a certificate to operate between points in Utah, which was denied on the ground that the field was adequately served and the denial sustained by the Utah Supreme Court. Wycoff Co. v. Public Service Commission, 227 P.2d 323 (Utah 1951).

10 Wycoff Co., Inc., v. Public Service Commission of Utah, 195 F.2d 252 (10th Cir. 1951 ). The district court opinion is unreported.

11344 U.S. 237, 245 (1952).

$12 I d$. at 246.

13 Id. at 247 . 
It also involves a rationalization in practical terms of the effects of administrative "action."

Passing for the moment the conceptualistic inquiry, it will be appropriate to examine the situations in which the federal courts appraised the risks entailed by the state administrative action as sufficiently serious to take jurisdiction of federal-state conflicts in regulation. Where the state agency has heard and denied a motion to dismiss the proceedings before it $^{14}$ or has already ordered hearings on the merits, ${ }^{15}$ there is at least an iminediate threat of contempt proceedings or other penalties for failure to participate in further proceedings or to comply with the order, in addition to the cost and inconvenience of participating in a hearing on the merits. But administrative action may be less formal, yet no less fraught with risk of harm. State officials may seize goods ${ }^{16}$ or by other summary methods secure compliance with state regulations without considering jurisdictional questions. ${ }^{17}$ They may refuse to excuse an applicant from a burdensome, stateimposed condition froin which federal regulation may exempt him. ${ }^{18}$ In more sensitive areas considerably more equivocal action may nevertheless create sufficient risk of harm. The institution of proceedings by a state labor board looking toward ultimate certification of a bargaining agent may upset established labor relations. ${ }^{19}$ The threatened enforcement of a village ordinance barring flights over the area could jeopardize the entire operations of Idlewild Airport in New York. ${ }^{20}$ A Pemısylvania censorship regula-

14 Rice v. Santa Fe Elevator Corp., 331 U.S. 218 (1947) (the mere threat of state regulation of a company operating under the Federal Warehouse Act was said to cast a cloud on titles held under the company's federal warehouse receipts) ; Limde Air Products Co. v. Johnson, 77 F. Supp. 656 (D. Minn. 1948) (motion to dismiss proceedings before state labor conciliator denied).

15 Public Utilities Commission v. United Fuel Gas Co., 317 U.S. 456 (1943) (jurisdictional objection overruled and company ordered to prove reasonableness of rates); Interstate Natural Gas Co. v. Public Service Counmission, 33 F. Supp. 50, 34 F. Supp. 980 (E. D. La. 1940) (jurisdictional objection overruled and rate hearing ordered).

16 Cloverleaf Butter Co. v. Patterson, 315 U.S. 148 (1942) (company's products seized under Alabania pure food law).

17 Kentucky Natural Gas Corp. v. Public Service Commission, 28 F. Supp. 509 (E.D. Ky. 1939), aff'd, $119 \mathrm{~F} .2 \mathrm{~d} 41$ ' (6th Cir. 1941) (jurisdiction assumed and rate investigation ordered).

18 Pennsylvania Greyhound Lines v. Board of Public Utility Conmissioners, 107 F. Supp. 521 (D. N.J. 1952) (permit to withdraw evidence of insurance coverage required by state law demed) ; National Broadcasting Co., Inc. v. Board of Public Utility Commissioners, 25 F. Supp. 761 (D.N.J. 1938) (order to show cause why state permit for construction of broadcasting station should not be sought). And see Johnson Transfer \& Freight Lmes v. Perry, 47 F. 2d 900 (N.D. Ga. 1931) ; Consolidated Gas Electric Light \& Power Co. v. Siggins, 99 F. Supp. 151 (N.D.Pa. 1951).

10 United Office \& Professional Workers v. Smiley, 77 F. Supp. 659 (M.D. Pa. 1948) ; Food, Tobacco \& Agricultural Workers v. Smiley, 74 F.Supp. 823 (E.D. Pa. 1946), aff'd, 164 F.2d 922 (3rd Cir. 1947).

20 All American Airways v. Cedarhurst, 106 F. Supp. 521 (E.D. N.Y. 1952), aff'd, 201 F.2d 273 (2d Cir. 1953). 
tion applicable to television was enjoined prior to any specific application. ${ }^{21}$ In all of these situations relief was given against further state proceedings.

The United and Wycoff decisions are the first apparently to depart from this hine of authority in holding that no risk of harm was shown justifying intervention. In the Wycoff case, however, there had been no action by the state Commission at all except for the filing of a petition for an injunction. Service was never made and no risk of harm was shown to exist at that time. In the United case the Commission had gone considerably further. The "instruction" given United to file its tariffs placed it in a real dilemma. If it complied, it invited an order that could conflict with federal regulations and that possibly could not be challenged without instant violation of either federal or state regulation entailing an attendant risk of fines and penalties. If it refused to comply, it risked immediate and probably non-enjoinable contempt proceedings ${ }^{22}$ for failure to obey the "instruction" and ultimately retroactive assessment of penalties for non-compliance. ${ }^{23}$ But these were risks, unlike those entailed in the cases where relief was given, subject to various contingencies and the decision that they did not justify the short cutting of the jurisdictional determination by the Commission is not necessarily inconsistent with prior decisions.

Nevertheless considerably less formal and pointed administrative action than occurred in the United case may affect the substantial rights of parties. The variety of the forms that such action may take is limited only by the imagination and inventiveness of legislatures and administrators. Letters, advices, policy declarations, press releases, oral statements and conditions attached to grants and permits all are manifestations of administrative behavior, and the party at which they are directed is rarely in a position to gauge accurately their ultimate effect. Courts, being in little better position to prognosticate, must therefore rely on their experience and exercise wide discretion in determining whether administrative action has indeed created a conflict with federal law and whether the risk of harm shown justifies intervention. The outcome of litigation in this field is likely to remain shrouded in uncertainty when the situation falls in the interstices between decided cases.

The difficulty of predicting the practical significance of administrative action - and the view that a federal court might take of it-is compounded

21 Allen B. DuMont Laboratories v. Carroll, 86 F. Supp. 813 (E.D. Pa. 1949), aff'd, 184 F.2d 153 (3rd Cir. 1950), cert. denied, 340 U.S. 929 (1951). And see Tampa Times Co. v. Burnett, 45 F. Supp. 166 (S.D. Fla. 1942).

${ }^{22}$ Cf. Atlantic Freight Lines v. Pennsylvania Public Utilities Commission, 109 F. Supp. 385 (W.D.Pa. 1952). See note 35 infra.

23 The Commission in its brief denied that it had power to assess penalties retroactively under the circumstances and asserted that in any event it would not do so. BRIEF of THE PUBLIC Utmities Comanisston iN the SUpreme Court, §§ I, A-E. 
by the existence of conceptualistic jurisdictional pigeonholes. Thus, in order to obtain an injunction, a hitigant must demonstrate that he is about to suffer "irreparable harm" and to obtain a declaratory judgment, he must establish the existence of a "justiciable controversy."

Of the two available remedies, injunctions and declaratory judgments, the former are more decisive and presumably more desirable. But the federal courts, once eager to enjoin state administrative regulation without regard to the traditional inhibitions on courts of equity, have become increasingly reluctant to interfere with state agencies. Equitable discretion to refuse relief has been given a wide compass and a firm doctrinal backbone. The principal doctrimes-exhaustion of administrative remedies and adequacy of legal remedies-are discussed in subsequent sections. But the doctrine of irreparable harm is a specially shadowy problem.

To require a showing of irreparable harm as a prerequisite to equitable relief against state action challenged on the ground of an unconstitutional taking of property makes sense. ${ }^{24}$ To apply the historic equity maxim to a situation where the alleged harm consists principally of the threat of state regulation of substantially the same nature as the federal regulation to which the plaintiff is already exposed makes very httle sense. Contempt, injunction and criminal proceedings may constitute irreparable injury although penalties presumably could be recovered if paid under protest and later sued for. But the point is that Congress has established the manner and extent of regulation of the person concerned and, if the plaintiff is correct, conflicting or supplementary state action would interfere with the Congressional purpose. The limitations of federal regulation may be as important as their substance. The circumscription of certain conduct often evidences an intention that there should be no further prohibitions. ${ }^{25}$ If state administrative action were left free to operate and no relief were available until the entire administrative process were exhausted and the highest court had ruled on all of the substantive questions involved, it would seem that any Congressional intention to lay out an area of freedom as well as of regulation will have been irreparably frustrated, as to the litigant as well as to others in his class whose conduct will of course be affected by the pending litigation. ${ }^{26}$ This is the crux of harm in these cases of conflict and, in a practical sense, it is indeed irreparable. Although the courts do not usually spell it out, this reasoning is implicit in the conflict

\footnotetext{
${ }^{24}$ See, e.g., Petroleum Exploration, Inc. v. Public Service Commission, 304 U.S. 209 (1938).

${ }^{25}$ See Public Utilities Commission v. Umited Fuel Gas Co., 317 U.S. 456, 468 (1943); Linde Air Products Co. v. Johnson, 77 F. Supp. 656, 659 (D. Minn. 1948).

26 Cf. Order of Railway Conductors v. Pitney, 326 U.S. 561, 566 (1946): "Of course, where the statute is so obviously violated that a 'sacrifice or obliteration of a right which Congress ... created' to protect the interest of individuals or the public is clearly shown a court of equity could, in a proper case, intervene."
} 
cases. Injunctive relief has always been given as soon as the plaintiff could show that the state administrative agency was proceeding toward regulation of subject matter under federal regulation, ${ }^{27}$ unless, of course, the plaintiff's case failed on the merits. ${ }^{28}$

Declaratory judgments, ${ }^{29}$ on the other hand, are not subject to the "irreparable harm" requirement ${ }^{30}$ although the court has the discretion of a court of equity to refuse to give relief. ${ }^{31}$ The declaratory procedure, lowever, is encumbered by the requirement, growing out of the constitutional inhibition against the decision of abstract questions by the federal courts, that a "justiciable controversy" be shown to exist. ${ }^{32}$ Thus, the declaration requested in the Wycoff case that the plaintiff "operated in

27 See the cases cited in notes $14,16,19$ and 20 stspra. See also Public Utilities Commission v. United Fuel Gas Co., 317 U.S. 456 (1943); Jolnson Transfer \& Freight Lines v. Perry, 47 F.2d 900 (IN.D. Ga. 1931) ; Consolidated Gas Electric Liglit \& Power Co. v. Siggins, 99 F. Supp. 151 M.D.Pa. 1951); Tampa Times Co. v. Burnett, 45 F. Supp. 166 (S.D. Fla. 1942) ; National Broadcasting Co., Inc. v. Board of Public Utility Conmissioners, 25 F. Supp. 761 (D. N.J. 1938). In the following cases relief was given agamst state administrative action in conflict with federal law or regulation without discussion of the jurisdictional or procedural problems: Grandin Farmers' Co-op. Elevator Co. v. Langer, 5 F. Supp. 425 (D. N.D. 1934), aff'd, 292 U.S. 605 (1934); Atlantic Coast Line R. Co. v. Napier, 2 F.2d 891 (N.D. Ga. 1923); aff'd, 272 U.S. 605 (1926); Farmers' Grain Co. v. Langer, 273 Fed. 635 (8th Cir. 1921), aff'd, 258 U.S. 50 (1921); Southern Pacific Co. v. Peterson, 43 F.2d 198 (D. Ariz. 1930), subsequent opinion, 2 F. Supp. 855 (D. Ariz. 1933); Must Hatch Incubator Co. v. Patterson, 27 F.2d 447 (D. Orc. 1928); Staten Island Rapid Transit Ry. Co. v. Public Service Commission, 16 F.2d 313 (S.D. N.Y. 1926); Chicago \& Northwest Ry. Co. v. Railroad Commission, 280 Fed. 387 (D.Minn. 1922); Louisville \& Nashville Co. R. Co. v. Hughes, 201 Fed. 727 (S.D. Ohio 1912). In the following cases relief was given at the instance of a federal agency; N.L.R.B. v. Utah Industrial Commission, 84 F. Supp. 593 (D. Utah 1948), aff'd, 172 F.2d 389 (10th Cir. 1949) ; Farmers' Gin Co. v. Hayes, 54 F. Supp. 43 and 47 (W. D. Okla. 1943).

28 In the following cases jurisdiction was assumed but relief denied because the state and federal regulations were found not to conflict: Eichholz v. Hargus, 23 F. Supp. 587 (W.D.Mo. 1938), affd, 306 U.S. 268 (1939); Thompson v. McDonald, 95 F.2d 937 (5th Cir. 1938), affd, 305 U.S. 263 (1938) ; Barnwell Bros. v. South Carolina Highway Dept., 17 F. Supp, 803 (E.D. S.C. 1937), rev'd, 303 U.S. 177 (1938) ; Mintz v. Baldwin, 2 F. Supp. 700 (N.D.N.Y. 1933), aff d, 289 U.S. 346 (1933); Aerated Products Co. v. Department of Health, 59 F.Supp. 652 (D.N.J. 1945), aff d, 159 F.2d 851 (3rd Cir. 1947); United Drng Co. v. Graves, 34 F.2d 808 (M.D. Ala. 1929) ; Missouri-Kansas-Texas R. Co. v. Williamson, 36 F.Supp. 607 (W.D. Okla. 1941); Brashear Freight Lines, Inc. v. Public Service Commission, 23 F. Supp. 865 (W.D.Mo. 1938), appeal dismissed, 306 U.S. 204 (1939). For federal agency as the plaintiff, see N.L.R.B. v. New York Labor Relations Board, 106 F. Supp. 749 (S.D.N.Y. 1952).

2962 Stat. 964 (1948), amended 63 Stat. 105 (1949), 28 U.S.C. $\$ 2201$ (1952). In the following cases the declaratory procedure was employed: Kentucky Natural Gas Corp. v. Public Service Commission, 28 F. Supp. 509 (E.D. Ky. 1939), aff'd, 119 F.2d 417 (6th Cir. 1941) ; Pennsylvania Greyhound Limes v. Board of Public Utility Commissioners, 107 F. Supp. 521 (D. N.J. 1952); Allen B. DuMont Laboratory v. Carroll, 86 F. Supp. 813 (E.D. Pa. 1949); Interstate Natural Gas Co. v. Public Service Commission, 33 F. Supp. 50, 34 F. Supp. 980 (E.D. La. 1940). 30 See Nashville, C. \& St. L. Ry. Co. v. Wallace, 288 U.S. 249, 264 (1933) ; Note, 56 YaLE L.J. 139 (1946); BorCHARD, DecLaratory JudgMENTS 365 (2d ed. 1941).

${ }^{31}$ See Great Lakes Dredge \& Dock Co. v. Huffman, 319 U.S. 293, 300 (1943).

32 U. S. Const. ART. III, § 2; Muskrat v. United States, 219 U.S. 346 (1911). 
interstate commerce" was, as Justice Jackson pointed out, abstract and anticipatory, requiring further judicial consideration before it could form the basis for the decision of any particular controversy. ${ }^{33}$ One factor in this decision inay well have been the plaintiff's draftsmanship. Had it requested a declaration that its ICC certificate authorized existing operations between points in Utah and precluded the application of state certification requirements, the objection of abstractness might have been removed although the problem of whether a controversy actually existed at the time remained. This in fact was the type of declaration requested in the United case. That declaratory relief was denied in that case may rest rather on the second ground of the $W y$ coff decision, that is, that the court was asked to preempt the jurisdictional issue before the agency had had an opportumity to rule on it. ${ }^{34}$

B

Whether the federal court is asked, as Mr. Justice Jackson put it in the Wycoff opinion, to "preempt and prejudge issues that are committed for initial decision to an administrative body" is a problem of timing similar to that discussed in the preceding section. The difference is that here the concern is over the defendant rather than the plaintiff. In deciding the type of cases under discussion, courts undoubtedly weigh the magnitude of the risk of harm to the person subject to regulation against the agency's need for independence and integrity, and this section is concerned with the second part of that proposition. The inquiry is necessarily confined to the relation between federal courts and state agencies; the continuous supervision of federal courts over federal agencies and the questions of interpretation of the controlling federal statutes distinguish the problem of federal court-federal agency relations. ${ }^{35}$

${ }^{33}$ This may be termed the "so what" test of declaratory relief. 344 U.S. 237, 244 (1952). In that connection, Justice Jackson also suggested that under the circumstances, giving affirmative rehef on the ground of federal preemption would be giving what would normally be a defense the dignity of a cause of action. This would not seem to be an objection well-taken, however, where no expansion of federal jurisdiction results, i.e., where, as here, the primcipal issue is the federal question of state-federal conflict which confers jurisdiction on the federal courts regardless of how it is raised. See Developments in the Law-Declaratory Judgments, 62 HARv. L. REv. 787, 803 (1949).

34344 U.S. 237, 246 (1952).

$35 \mathrm{It}$ is interesting to observe, however, that there is no apparent thread of consistency in the cases involving questions of timing federal court interference with federal agencies. Compare Joint Anti-Fascist Refugee Committee v. McGrath, 341 U.S. 123 (1951), and United Public Workers v. Mitchell, 330 U.S. 75 (1947), with Eccles v. Peoples Bank, 333 U.S. 426 (1948), and Rochester Telephone Corp. v. United States, 307 U.S. 125 (1939). See Davrs, AdMInISTRATIve LAW \$\$ 194-196 (1951). Moreover it would be misleading and inappropriate to apply rules based upon highly technical and specialized statutory provisions governing federal regulatory schemes to the question when state action may be tested for conflict with federal law. In any event federal agencies remain under the continuing supervision and control 
As a general proposition the determination of its own jurisdiction is committed for initial decision to the administrative agency. ${ }^{36}$ Ordinarily this requires consideration of mixed questions of law and fact fallng within the field of the agency's expertise. In the United case it would have been appropriate for the Commission to hold hearings on and to consider the question whether it should regulate the Catalina tariffs in the light of state law and policy, Commission regulations and the proven facts of United's operations in California. A decision on the jurisdictional point rendered at the conclusion of this procedure would have satisfied the Commission's legitimate interest and would have established irrefutably whether or not there was in fact a jurisdictional controversy justifying judicial intervention. It would seem, therefore, that at this point, but before a hearing on the merits of the case itself, the question of conflict would have been ripe for federal court review. ${ }^{37}$

The procedure suggested for United depends on the party's ability to raise the jurisdictional point before the agency and on the agency's willingness to hear it. Presumably some form of procedure is available before nearly every agency by which its attention may be called to the question of its jurisdiction. We have seen, however, that much administrative action occurs in conscious or unconscious disregard of that question. This may be in part because action occurs at a level where such considerations are not a part of the modus operandi. In Cloverleaf Butter Co. v. Patterson, ${ }^{38}$ for example, state agents proceeded to seize goods which they believed were sold and transported in violation of the state pure food law. When this occurs, there may not be an adequate procedure for tinely challenge before the agency itself. It may also be that the agency will refuse to consider jurisdictional questions, either because it has no doubts on the point or because it believes the time is not yet ripe. In this connection the court must again cope with the almost limitless imagination of administrators and legislators in devising forms and means of regulation..$^{30}$ In ascertaining whether it is asked to preempt and prejudge an issue committed for initial decision to the agency, the court nuust therefore determine whether the agency will in fact make a timely determination of the issue. The cases

of federal courts but state administrative action may be removed from federal jurisdiction when it has been taken to the state courts where the federal district courts are not likely to interfere. See Atlantic Freight Lines v. Pennsylvania Public Utilities Commission, 109 F. Supp. 385 (W.D.Pa. 1952). But cf. Red Rock Cola Co. v. Red Rock Bottlers, 195 F.2d 406 (5th Cir. 1952). This may have been a factor in the $W y c o f$ case where the Commission had taken its case to the state court before federal court relief was sought, and one imposing a considerable tactical burden on the litigant.

${ }^{36}$ Cf. Macauley v. Waterman Steamship Corp., 327 U.S. 540, 542 (1946).

37 See the cases cited in notes 14 and 15 supra.

38315 U.S. 148 (1942).

${ }^{30}$ See text at note 23 et seq. supra. 
heretofore discussed indicate that federal courts will step in when the agency has taken a firm stand by ruling on its jurisdiction ${ }^{40}$ or by refusing to rule and proceeding to the merits by way of hearing or other action having a regulatory effect. ${ }^{41}$ If the agency equivocates when its jurisdiction is challenged before it, but its conduct indicates that in terms of results it will in fact regulate before considering jurisdiction, the action of the federal court should be the same as if jurisdiction had been fornally assumed. ${ }^{42}$.

The doctrine of exhaustion of administrative remedies does not apply here. The purpose of the doctrine is to prevent preemption by the courts of matters delegated to agencies. In the leading case of Myers v. Bethlehem Shipbuilding Corp..$^{43}$ for example, it was applied to prevent the courts from prejudging the question whether the conduct involved affected interstate commerce, a question which Congress clearly had left to the special competence of the National Labor Relations Board. The question whether Congress has barred state jurisdiction in the area in which a state agency is about to act is not one within the state agency's special competence. ${ }^{44}$

40 See cases cited in note 14 supra.

41 See Pennsylvania Greyhound Lines v. Board of Public Utility Commissioners, 107 F. Supp. 521 (D. N.J. 1952) ; Food, Tobacco \& Agricultural Workers v. Siniley, 74 F. Supp. 823 (E.D. Pa. 1946).

42 See the discussion in text at notes 14-21 supra, and cases cited in notes 19-21 supra. Federal court relief may be interlocutory and not inconsistent with further full consideration of the legitimate interests of the state. See All American Airways v. Cedarhurst, 106 F. Supp. 521 (E.D.N.Y. 1952), aff'd, 201 F.2d 273 (2d Cir. 1953).

43303 U.S. 41 (1938).

$44 \mathrm{It}$ has been said that the doctrine of the Myers case in fact supports timely rehef by federal courts against state administrative action where Congress has occupied the field because this protects the exclusive jurisdiction of federal agencies against interference. See United Office \& Professional Workers v. Smiley, 77 F. Supp. 659, 671 (M.D. Pa. 1948). Whether the jurisdiction of the federal agency has actually been invoked in the particular case, however, sliould be irrelevant to the district court's jurisdiction to give relief. "The question is not, however, whether the N.L.R.B. has acted in determining the appropriate bargaining unit; rather, it is whether Congress bas asserted its power to regulate tbat relationship." Linde Air Products Co. v. Johnson, 77 F. Supp. 656, 658 (D.Minn. 1948). Presumably the result should be the same if the federal agency lias previously exercised its discretion by refusing to take jurisdiction. BethIchein Steel Co. v. New York State Labor Board, 330 U.S. 767, 773 (1947). But in Alameida Bus Lines Inc. v. Curran, 209 F.2d 680 (1st Cir. 1954), relief against state action was denied for lack of equity. The plaintiff lad previously succeeded in having the National Board dismiss the unfair labor practice complaint against it on the ground that at the time tle acts were conlmitted plaintiff had no reason to know that it would be subjected to the Board's jurisdiction. Denial of federal jurisdiction in this case did not imply an intention to exclude state jurisdiction. The court distinguisled cases heretofore cited on the ground that the suit before it involved remedies for past conduct rather than regulation of prospective conduct. Whether adjudication of past conduct by a state agency conflicts with the federal scheme wonld seen to be a question no different in its "essential aspects from the question of conflict in prospective regulation. Sinilarly, the question whether state action is barred unequivocally or whether it is permissible after a federal refusal of jurisdiction is a substantive question of federal-state conflict for the federal court. It seems inevitable that the federal court will be strongly influ- 
Once the state body has determined that under state law it has jurisdiction, there are no issues of special fact or administrative expertise pertinent to jurisdiction left. ${ }^{45}$ If it is true that Congress, as alleged, has barred the states from regulating the subject, it would be a contradiction in terms to apply the doctrine of exhaustion because in such a case Congress left the state agency no remedy at all to give the litigant. The litigant cannot be accused of trying to escape from the "necessity of a trial to establish the fact" 40 when he is asserting the freedom from state regulation which, if he is correct, Congress intended to establish. It has been pointed out heretofore that Congress' purpose can be effectively frustrated by quasi-regulation resulting from long delay and postponement before the question of federalstate conflict may be raised effectively before the federal court. ${ }^{47}$

It may be argued that, by the same token, federal district courts nray interrupt state adninistrative proceedings at an early stage on the ground that they threaten to violate the Fourteenth Amendment, the Commerce Clause or some other constitutional right. But those situations are distinguishable. The question of confiscation is one of fact and of policy. Suppose United, instead of challenging the jurisdiction of the state Commission, had applied for authority to abandon its Catalina flight on the ground that, expenses exceeding revenue, continued operation would deprive United of its property without due process. This would have necessitated consideration of the public need for the service, the effect of the losses on the carrier, the relation of the particular service to the transportation system as a whole and other factual and policy questions within the Commission's expertise before constitutional tests could be applied. ${ }^{48}$ Or suppose United had challenged the jurisdiction of the state Commission on

enced by a prior refusal of jurisdiction by a federal agency and will be tempted to dispose summarily of a case where the litigant appears to be playing botb ends against the middle. See $i d$. at 681 .

45 This is not a matter "raising issues of fact not within tbe conventional experience of judges or ... requiring the exercise of administrative discretion ... (or) (u)niformity and consistency in the regulation of business entrusted to a particular agency . . . ." Far East Conference v. United States, 342 U.S. 570, 574 (1952). It is true that the courts occasionally do make exceptions to the exhaustion doctrine but the subject under discussion is not one of them. See Davis, Admontstrative LAw 623 (1951). What is involved is a jurisdictional question for the courts. See Great Northern Railway v. Merchant's Elevator Co., 259 U.S. 285, 291 (1922) ; Note, 51 HARv. L. REv. 1251 (1938). "(T) he commanding circumstances of the present case (are) (f)irst, and most important, the orders of the state Commission are on their face plainly invalid. No inquiry beyond the orders themselves and the undisputed facts which underlie them is necessary in order to discover that they are in conflict with the federal Act." Public Utilities Conımission v. United Fuel Gas Co., 317 U.S. 456, 468 (1943). See also Lillionthal, The Federal Courts and State Regulation of Public Utilities, 43 Harv. L. Rev. 379 (1930).

40 Petroleum Exploration, Inc. v. Public Service Conımission, 304 U.S. 209, 221 (1938).

47 See the discussion in text at notes 24-30 supra.

48 See Alabama Public Service Commission v. Southern Ry. Co., 341 U.S. 341 (1951), text at note $53 \mathrm{ff}$. infra. 
the ground that it interfered with interstate commerce. Again it would have been appropriate, in the first instance, to consider the technical factors bearing on the legitimacy of the state's interest in the service-the degree of connection with intrastate commerce, and other realities that give content to the Commerce Clause. ${ }^{49}$ These are all matters on which a court will rightly defer to the agency for primary determination, impelled by respect for technical expertness and by reluctance to pass on constitutional issues. ${ }^{30}$

Whether actual or imminent interference by a state agency in a field conflicts with federal law or regulation is a different sort of question and cases turning on constitutional issues should be carefully distinguished..$^{51}$ If the $\mathrm{CAB}$ in fact has exclusive jurisdiction over air carriers flying over the high seas, no reason appears why a state agency should be permitted to conduct lengthy and expensive regulatory proceedings against an air carrier subject to that exclusive jurisdiction. Once the agency has determined, therefore, that it has jurisdiction, or proceeds on that assumption, the crucial question is whether federal action has ousted state jurisdiction. That question at that stage is properly one for the federal court to decide. ${ }^{52}$

C

The final problem concerns the right of state administrative bodies to administer state policy and the proper relationship between the federal courts and state administrative agencies. The latest word on this point is Alabama Public Service Commission v. Southern Raitway Co ${ }^{53}$ The Southern Railway had applied to the Alabaina Commission for authority to

${ }^{49}$ See note 69 infra. In spite of the procedural differences between the treatment of questions of Constitutional interpretation and of statutory interpretation, interference with interstate commerce and statutory federal-state conflict are not always properly distinguished in the cases. See Gulf, M. \& O. Ry. Co. v. Louisiana Public Service Commission, 120 F. Supp. 250 (E.D.La. 1954); Dolırn Transfer Co. v. Hoegh, 116 F. Supp. 177 (S.D. Iowa 1953).

50 See, generally, Prentis v. Atlantic Coast Line R. Co., 211 U.S. 210 (1908), and Ashwander v. Tennessee Valley Authority, 297 U.S. 288, 345-348 (1936), progenitors of administrative sanctity and constitutional reluctance. See Note, 52 MicH. L. REv. 567, 573 (1954).

51 The distinction is reflected in the application of 28 U.S.C. $\$ 2281$ (1952) which provides that injunctions against state administrative action "upon the ground of the unconstitutionality of such statute" shall only be granted by a three-judge district court. "The declaration of the supremacy clause gives superiority to valid federal acts over conflicting state statutes, but this superiority for present purposes involves merely the construction of an act of Congress, not the constitutionality of the state enactunent." Ex parte Bransford, 310 U.S. 354 (1940). Although the quoted proposition is unquestioned, see, e.g., Rice v. Santa Fe Elevator Corp., 156 F.2d 33, 36 (7th Cir. 1946), aff'd, 331 U.S. 218 (1947), state-federal conflict cases are occasionally heard by three-judge district courts, which can usually be attributed to the fact that a constitutional question was raised in the pleadings though later not pressed or not decided. See United Air Lines, Inc. v. Public Utilities Commission, 346 U.S. 402 (1953).

62 An early federal court learing has the further advantage of giving the federal agency concerned an opportunity to express its views on a matter of importance to it.

53341 U.S. 341 (1951). 
abandon intrastate passenger service on two trains on the ground that it was uneconomical. Permission having been denied, and administrative remedies having been exhausted, the company filed suit in the federal district court, resting jurisdiction on diversity of citizenship and alleging confiscation of its property in violation of the Fourteenth Amendment. The three-judge district court granted an injunction against enforcement of the Commission's order denying permission to abandon service, but on appeal the Supreme Court reversed.

Chief Justice Vinson, for the majority, found that judicial review of both law and facts was an integral part of the procedure under Alabama law and that the state courts had power to direct a stay or supersedeas of an order pending appeal. He went on to say: ${ }^{64}$

As adequate state court review of an administrative order based upon predominantly local factors is available to appellee, intervention of a federal court is not necessary for the protection of federal rights. Equitable relief may be granted only when the District Court, in its sound discretion exercised with the "scrupulous regard for the rightful independence of state governments which should at all times actuate the federal courts," is convinced that the asserted federal right cannot be preserved except by granting the "extraordinary relief of an injunction in the federal courts." Considering that " $[\mathrm{f}] \mathrm{ew}$ public interests have a higher claim upon the discretion of a federal chancellor than the avoidance of needless friction with state policies," the usual rule of comity must govern the exercise of equitable jurisdiction by the District Court in this case. Whatever rights appellee may liave are to be pursued through the state courts.

The case is, of course, distinguishable because the plaintiff's challenge rested on constitutional grounds, not on an allegation of conflict between state and federal enactments. As its broadest implications challenge the thesis of this article, however, it deserves attention. Justice Frankfurter, dissenting with Justice Jackson, read the majority opinion as requiring abstention by the federal courts whenever state administrative orders could be reviewed by a state court. ${ }^{55}$ Whether one agrees with the Alabama decision or not, a point not pertinent to the present discussion, it is believed that analysis will prove the case to have a more restricted meaning which does not bar early access to the federal courts in state-federal conflict cases.

The Alabama case is the latest piece to be fitted into the jigsaw pattern of rules of restraint governing the federal courts. The restraints are both legislative and judicial. Congress over the years has yielded to many different pressures and demands in restricting the jurisdiction of the federal courts to interfere with state administrative processes. The pertinent statutes are well known but none apply to the present problem of conflict

\footnotetext{
54 Alabama Public Service Commission v. Southern Railway Co., 341 U.S. 341, 349-50 (1951).

55 Id. at 356 .
} 
between federal and state law and regulation. ${ }^{56}$ Of the judicially imposed restraints, the doctrines of irreparable harm ${ }^{57}$ and of Myers v. Bethlehem Shipbuilding Corp. ${ }^{58}$ and Ashwander v. Tennessee Valley Authority ${ }^{59}$ have heretofore been discussed..$^{60}$ There remain three principles of restraint, upon which the Alabama case rests, which require analysis here.

When a controversy may be terminated by a ruling on a doubtful question of state law, federal equity courts will stay their hand. In Railroad Commission of Texas v. Pullman Co. ${ }^{61}$ an order of the Commission was challenged on the ground that it discriminated against Pullman porters in violation of the Fourteenth Amendment. The Supreme Court ordered the district court to stay its proceedings because " $[\mathrm{t}]$ he law of Texas appears to furnish easy and ample means for determining the Commission's authority." "2 Undoubtedly the "[i]nterpretation of state legislation is primarily a function of state authorities, judicial and administrative." ${ }^{63}$ A point is reached, however, when federal courts, actuated by Erie Railroad $C o$. $v$. Tompkins, ${ }^{64}$ can no longer refuse to decide questions of state law. In any case of attack on state administrative regulation on the ground of conflict with federal law, although federal law is the principal issue, the possibility of a pertinent ruling on state law exists. ${ }^{65}$ But the Alabama case itself seems to indicate that the mere existence of such a possibility does not compel federal court abstention. Meredith $v$. Winter Haven, ${ }^{66}$ the court noted, sustained the exercise of federal jurisdiction in a case involving matters of state law where decision " 'does not require the federal court to determine

56 The legislation is reviewed by Justice Frankfurter in his dissenting opinion in Alabama Public Service Commission v. Southern Railway Co., 341 U.S. 341, 357-358 (1951). The principal provisions are for three-judge courts, direct appeals to the Supreme Court and conditional stays of federal court proceedings when a state statute and action under it are attacked as unconstitutional. 36 STAT. 539, 557 (1910), 37 STAT. 1013 (1913), 43 STAT. 936, 938 (1925), 28 U.S.C. $\$ \S 2281-2284$ (1952). Congress has also passed the Johnson Act, restricting jurisdiction over state rate orders, 48 STAT. 775 (1934), 28 U.S.C. $\$ 1342$ (1952), and has prohibited interference with state tax statutes, 50 STAT. 738 (1937), 28 U.S.C. § 1341 (1952). See HART and Wechsler, The Federal Courts and tae Federat System 846-866 (1953).

57 See text at notes 24-30 supra.

58303 U.S. 41 (1938); see text at notes $40-46$ supro.

60297 U.S. 288 (1936); see text at note 48 et seq. supra.

60 Gulf Oil Corp. v. Gilbert, 330 U.S. 501 (1947), (federal court forum non conveniens); see also Great Lakes Dredge \& Dock Co. v. Huffman, 319 U.S. 293 (1943) (refusal to enjoin collection of state tax); Douglas v. City of Jeanette, 319 U.S. 157 (1943) (refusal to enjoin state criminal proceedings); see Notes, 52 MTCH. L. REv. 567 (1954), 46 ILI. L. REv. 756 (1951).

61. 312 U.S. 496 (1941).

62 Id. at 501 .

63 Albertson v. Millard, 345 U.S. 242, 244 (1953).

64304 U.S. 64 (1938).

65 See the dissenting opinion in Rice v. Santa Fe Elevator Corp., 331 U.S. 218, 240 (1947).

The dissent was mainly grounded on the merits, however.

66320 U.S. 228 (1943). 
or shape state policy governing administrative agencies' and 'entails no interference with such agencies or with the state courts.' "67

This statement leads to the second relevant principle of restraintwhere the matter at issue "clearly involves basic problems of [state] pohicy ... equitable discretion should be exercised to give the [state] courts the first opportunity to consider them." ${ }^{68}$ Where, as in the Alabama case, technical and local problems are involved which the state has placed in the charge of a specialized administrative system with judicial review as an integral part, it cannot be said that federal-state relations will not be aided by the refusal of extraordinary federal court remedies pending completion of state processes. Where the issue is confined, however, to whether Congress has ousted the states from a particular administrative jurisdiction, exhaustion of state processes would not seem necessary to protect their integrity. ${ }^{69}$ This is true not only because the issue raised is one primarily for the federal courts to decide but also because the effect of the decision may be circumscribed. Although an attack based on federal preemption may in fact be directed against an entire state regulatory scheme, it is more likely that it will merely serve to exclude a particular operation or person from the state scheme without otherwise interfering with its administration or with its underlying policy. An injunction in favor of United would not have affected California's schene of regulation of intrastate airline tariffs. Relief granted to Wycoff would not have interfered with Utah's regulation of motor carriers lacking ICC certificates. Injunctions against representation proceedings involving parties subject to the national act did not strike down state labor regulation. Other cases, of course, may result in crippling a substantial part of the state's scheme, but these appear to be exceptions. Ordinarily the court's order granting relief is narrow and, in any event, nuay be interlocutory pending full determination and review of the substantive issues. ${ }^{70}$

Finally, it has been suggested that federal courts will desist where an adequate reniedy is available in the state courts. Taken out of context, the statement in the Alabama case that "[a]ppellee has not shown that the Alabama procedure for review of Commission orders is in any way inadequate to preserve for ultimate review in this Court any federal questions arising out of such orders" ${ }^{71}$ suggests such a primciple. It is not likely

67341 U.S. 341,351 n.15 (1951).

68 Burford v. Sun Oil Co., 319 U.S. 315, 332 (1943).

69 "Findings that a local agency may make will sometimes aid in reducing friction between the state and federal governments by exposing facts which indicate that the state has a legitimate concern in a complex situation where local and interstate interests are intertwincd. No such situation is presented here." Douglas, J., dissenting in Public Utilities Commission v. United Air Lines, Inc., 346 U.S. 402, $403-404$ (1953).

${ }^{70} \mathrm{See}$, e.g., All Amcrican Airways v. Cedarhurst, 201 F.2d 273 (2d Cir. 1953).

71341 U.S. at 349. 
that this was intended. The dissent states the doctrine, probably too well settled to be overruled by implication, that adequacy of the legal remedy is measured solely by the remedy available on the law side of federal courts once a case is stated within the statutory tests of federal jurisdiction. ${ }^{\text {2 }}$ An equity court may, of course, refuse jurisdiction on the ground that the remedy at law is adequate - which is not likely to be true where conflicting state regulation is challenged-but the fact alone that a state court may entertain the suit has not been recognized as a sufficient ground for equitable abstention. ${ }^{73}$ It is more likely that what the majority in the Alabama case intended was to give the states an opportunity to develop their own administrative policies on matters of local concern by the use of the machinery provided by state law. In such cases it is entirely fitting that the federal courts should stay their hand until the administrative and the judicial processes provided by the state lave been exhausted. Cases of this nature should not be confused with cases of federal-state regulatory conflicts where the issue is the reach of the federal statute. In those cases the reasons for restraint are absent and the federal courts are the logical tribunals to decide the question of conflict in the first instance.

D

Although the federal courts have many times been asked to give relief against threatened state administrative proceedings on the ground that they would conflict with federal law or regulations, these cases do not appear to have been heretofore categorized as such. Analysis of these cases, arising under the Supremacy Clause, indicates that they are indeed umique and not to be confused with cases involving the validity of state action under the Fourteenth Amendment or the Commerce Clause.

Until recently the federal courts have not hesitated to take jurisdiction of federal-state regulatory conflicts as soon as they became imminent and have refused relief only when the plaintiff failed to prove the existence of a conflict. The decisions in the Wycoff and United Air Lines cases may have somewhat disturbed this uncomplicated state of affairs. It is too early to tell whether these decisions were intended to change the law but they do not necessarily liave this effect. What they do in any event is to clarify the law and remind litigants of the procedure that ought to be followed.

Before a litigant asks the federal court for protection against state admimistrative action, lie must be able to show that the agency is taking action in a field from which it is excluded by federal law or regulation and is exposing him to an immediate risk of penalty, compulsion or other harm.

72 See 341 U.S. 341,359 and cases cited.

73 Meredith v. Winter Haven, 320 U.S. 228 (1943) (jurisdiction based on diversity of citizenship); Willcox v. Consolidated Gas Co., 212 U.S. 19 (1909) (jurisdiction based on federal question). 
It is not necessary that there be actual formal regulation but it would seem necessary that state action is sufficiently definable that a concrete and effective order can be entered by the federal court. It is not necessary that the agency has made a formal determination of its jurisdiction but it should have been given the opportumity to do so and its actions must be such that a conflict of jurisdiction is clearly made to appear.

The doctrine of exhaustion of administrative remedies is not applicable to this situation because there are no administrative remedies to exhaust. The question to be decided first, as soon as the state agency appears to have asserted jurisdiction, is whether federal law, in the hight of the Supremacy Clause, excludes state action. This is a pure question of law within the expertise of the federal court and failure of a timely decision will frustrate the intent of Congress and will expose persons to regulation and control of which they were meant to be free.

By the same token there is no occasion in these cases for federal courts to stay their hand in favor of the administrative and judicial processes of the state. Regard for the rightful independence of state governments is not at issue when the question before the court is the reach of a federal statute or regulation. The opportunity for an early and authoritative resolution of federal-state regulatory conflicts should ease rather than create federalstate friction.

Finally, respect for the integrity of administrative agencies and the rightful independence of state governments ought not to obscure the interest in having litigants "save tedious and costly litigation by ascertaining at the outset the controlling fact or law involved, thus either concluding the litigation or thereafter confining it within more precise limitations."74

74 H.R. Rep. No. 1264, 73d Cong., 2d Sess. 2 (1934) on the Declaratory Judgment Act, quoted in Justice Douglas' dissenting opinion in Public Utilities Commission v. United Air Iines, Inc., 346 U.S. 402, 404 (1953). 